\title{
Numerical Taxonomy of Moderately Halophilic Gram-negative Rods from an Inland Saltern
}

\author{
By ANA DEL MORAL, ${ }^{1 *}$ BERNARDO PRADO, ${ }^{2}$ EMILIA QUESADA ${ }^{1}$ \\ TERESA GARCÍA, ${ }^{3}$ RITA FERRER ${ }^{1}$ AND \\ ALBERTO RAMOS-CORMENZANA ${ }^{1}$ \\ ${ }^{1}$ Department of Microbiology, Faculty of Pharmacy, University of Granada, Granada, Spain \\ ${ }^{2}$ Laboratory of Microbiology, Institute of Biology, Catholic University of Valparaiso, \\ Valparaiso, Chile \\ ${ }^{3}$ Department of Microbiology, Faculty of Pharmacy, University of Sevilla, Sevilla, Spain
}

(Received 11 June 1987; revised 15 September 1987)

\begin{abstract}
A total of 174 moderately halophilic bacteria was isolated from an inland saltern with athalassohaline characteristics, located in La Malá, Granada, Spain. The results of 118 phenotypic tests were submitted to a numerical analysis with ten reference strains using simple matching $\left(S_{S M}\right)$ and Jaccard $\left(S_{J}\right)$ coefficients. Clustering was done by the unweighted pairgroup method of association (UPGMA), single linkage and complete linkage analysis. Five phenons were found at the $67 \%$ similarity level $\left(S_{S M}\right)$. Phenon A included 74 strains assigned to Vibrio; 22 bacteria belonging to phenon B were assigned to the genus Alteromonas; strains of phenon C were assigned to Deleya (43 strains) and Acinetobacter ( 7 strains); phenon D resembled Pseudomonas (13 strains); phenon E could be related to Flavobacterium oceanosedimentum ( 9 strains).
\end{abstract}

\section{INTRODUCTION}

Moderately halophilic bacteria have been defined as those showing optimal growth between 0.5 and $2.5 \mathrm{M}-\mathrm{NaCl}$ (Kushner, 1978, 1985). We have previously found a surprising variety of such organisms in hypersaline waters and saline soils (Quesada et al., 1982, 1983, 1987; Rodriguez-Valera et al., 1985; Ventosa et al., 1982, 1983), both of which are thalassohaline habitats. However, there have been few studies on the presence and distribution of moderately halophilic bacteria in athalassohaline environments.

The most abundant organisms in the solar salterns we have studied were representatives of the genera Pseudomonas, Alteromonas and Alcaligenes, followed by Vibrio strains, with small numbers of Flavobacterium and Acinetobacter spp. (Rodriguez-Valera et al., 1985). Grampositive cocci of the genera Planococcus and Sporosarcina were also found (Ventosa et al., 1983). In hypersaline soils, however, the most abundant organisms were identified as Deleya halophila (Quesada et al., 1984).

In previous work, we examined the distribution and types of heterotrophic halophilic bacteria found in an athalassohaline inland saltern (Del Moral et al., 1987). Here we make a detailed taxonomic study of a large number of moderately halophilic Gram-negative rods isolated from this athalassohaline environment to compare these with organisms isolated from other saline environments.

\section{METHODS}

Bacterial strains. The 174 strains selected for this study were isolated from water samples taken from ponds of a saltern that has been described in physical and chemical terms in a previous study (Del Moral et al., 1987). Samples were collected in June, July, August, September and October 1983-1984 (ten samples from six different sites). 
Methods for the isolation and further selection of the strains have been previously described (Del Moral et al., 1987). The following moderately halophilic bacteria were also included in the study: Deleya halophila CCM 3662 , 'Pseudomonas halosaccharolytica' CCM 2851, Vibrio costicola NCMB 701, Sporosarcina halophila DSM 2226, Halomonas elongata ATCC 33173, 'Flavobacterium halmophilum' CCM 2831, Paracoccus halodenitrificans CCM 286, Planococcus halophilus NRCC 14033, Micrococcus halobius NCMB 2591 and 'Micrococcus varians var. halophilus' CCM 3316. Quotation marks indicate those species which are not in the Approved Lists of Bacterial Names (Skerman et al., 1980) and its supplement (Moore et al., 1985).

Maintenance medium. The strains were maintained on agar slants of a medium comprising $10 \%(\mathrm{w} / \mathrm{v})$ marine salts (Subov, 1931), yeast extract (Difco), $1 \%(\mathrm{w} / \mathrm{v})$; proteose peptone no. $3(\mathrm{Difco}), 0.5 \%(\mathrm{w} / \mathrm{v}) ;$ glucose, $0.1 \%$ $(\mathrm{w} / \mathrm{v})$. This medium was solidified with Bacto-agar (Difco), $2 \%(\mathrm{w} / \mathrm{v})$. The $\mathrm{pH}$ was adjusted to $7 \cdot 2 \mathrm{with} 1 \mathrm{M}-\mathrm{NaOH}$.

Phenotypic tests. The 174 isolates and the 10 reference strains were studied for 118 phenotypic characteristics, including morphological, physiological, biochemical, nutritional and antibiotic susceptibility tests (see Table 1). All of the tests have been previously described (Ventosa et al., 1982; Quesada et al., 1984, 1985, 1987). All media contained $10 \%(\mathrm{w} / \mathrm{v})$ marine salts and were supplemented with nutrients as in the maintenance medium. The $\mathrm{pH}$ was adjusted to $7 \cdot 2$ with $1 \mathrm{M}-\mathrm{NaOH}$ and the incubation temperature was $32^{\circ} \mathrm{C}$.

Numerical analysis. A total of 118 tests was used for numerical analysis. Positive and negative results were coded as 1 and 0 , respectively; non-compatible or missing data were coded as 9 . Strain similarities were estimated with both simple matching $\left(S_{S M}\right)$ (Sokal \& Michener, 1958) and Jaccard $\left(S_{J}\right)$ (Jaccard, 1908) coefficients and clustering was achieved by the unweighted pair-group method of association (UPGMA), single linkage and complete linkage analysis (Sneath \& Sokal, 1973). The cophenetic correlation was obtained for each method (Sneath \& Sokal, 1973). The test error was estimated by examining 17 strains in duplicate (Sneath \& Johnson, 1972). The computation was done using the MINT program of Dr F. J. Rolf of the Department of Ecology and Evolution, State University of New York at Stony Brook, NY, USA, and an Eclipse model MV/10000 computer in the Computer Centre of the University of Granada.

Electron microscopy. Representative strains from each phenon were grown to mid-exponential phase on the surface of maintenance medium plates covered with the same liquid medium. Samples from the liquid cultures were negatively stained with a $2 \%(\mathrm{w} / \mathrm{v})$ phosphotungstic acid solution $(\mathrm{pH} 7 \cdot 0)$ and examined in an EM 10C/CR high-resolution transmission electron microscope, operating at $80 \mathrm{kv}$.

DNA base composition. Exponential-phase cells of representative strains from each phenon were ruptured and their DNA was purified using the method of Marmur (1961). The $G+C$ content of the DNA was determined from the midpoint value of the thermal denaturation profile (Marmur \& Doty, 1962). The $T_{\mathrm{m}}$ was determined following the graphic method described by Ferragut \& Leclerc (1976) and the G $+\mathrm{C}$ content was calculated from this temperature by using the equation of Owen \& Hill (1979) using standard saline citrate $(0 \cdot 15 \mathrm{M}-\mathrm{NaCl} / 0 \cdot 015 \mathrm{M}-$ trisodium citrate, $\mathrm{pH} 7.0$ ) (SSC). The $T_{\mathrm{m}}$ value of reference DNA from Escherichia coli NCTC 9001 was taken as $74.6{ }^{\circ} \mathrm{C}$ in $0 \cdot 1 \times$ SSC (Owen \& Pitcher, 1985).

\section{RESULTS}

All the strains studied were Gram-negative rods. Conspicuous polybetahydroxybutyrate inclusions were observed in the majority of strains. The 174 strains grew optimally in 5-20\% $(\mathrm{w} / \mathrm{v})$ salts media and were thus considered as moderate halophiles (Kushner, 1985). Most of them required at least $3 \%(\mathrm{w} / \mathrm{v})$ salts for growth (see Table 1$)$. The detailed results of all the physiological, biochemical, nutritional and antibiotic susceptibility tests are summarized in Table 1 .

\section{Numerical analysis}

Analysis of the 174 moderately halophilic bacteria using the $S_{S M}$ coefficient with UPGMA clustering yielded the dendrogram shown in Fig. 1. $S_{J}$ and single-linkage and complete-linkage algorithms were also used, but cluster composition was not affected by the coefficient or clustering method used. The cophenetic value for the $S_{S M}$ UPGMA analysis was 0.90 and the estimated test error was less than $3.6 \%$, which would not significantly affect the cluster analysis (Sneath \& Johnson, 1972).

As shown in Fig. 1, the majority of the strains were grouped into five phenons at a $67 \%$ similarity level $(67 \% S)$. Sixteen strains did not cluster at this level, including the 10 reference strains. The features of the five phenons are shown in Table 1 and this summarizes their differential characteristics.

Phenon A. A total of 74 strains formed this phenon at a $79 \% S$. They were curved rods, motile by a single polar flagellum, facultatively anaerobic, catalase and oxidase positive. Metabolism of 
Table 1. Frequencies of positive characters found in the five phenons (expressed as a percentage of the total scored to each group for the given test)

All strains were Gram-negative, produced catalase, grew at $7 \cdot 5,10$ and $12.5 \%(\mathrm{w} / \mathrm{v})$ total salts, at $\mathrm{pH} 7$ and at 25,32 and $37^{\circ} \mathrm{C}$. None formed indole. All were sensitive to chloramphenicol.

\begin{tabular}{cccccc} 
& \multicolumn{4}{c}{ Phenon } \\
\cline { 2 - 6 } & B & C & D & E \\
No. of strains . . & 22 & 50 & 13 & 9
\end{tabular}

\begin{tabular}{|c|c|c|c|c|c|}
\hline \multicolumn{6}{|l|}{ Morphology } \\
\hline Long rods* & 0 & 100 & 86 & 100 & 100 \\
\hline Coccobacillary* & 100 & 0 & 14 & 0 & 0 \\
\hline Motility* & 100 & 100 & 86 & 84 & 0 \\
\hline PHB & 100 & 100 & 100 & 100 & 100 \\
\hline \multicolumn{6}{|l|}{ Salts: growth at $\%(w / v)$} \\
\hline $0 \cdot 5$ & 3 & 13 & 10 & 0 & 0 \\
\hline 3 & 93 & 77 & 86 & 15 & 66 \\
\hline 5 & 96 & 86 & 96 & 46 & 66 \\
\hline 15 & 100 & 100 & 98 & 92 & 100 \\
\hline 20 & 97 & 91 & 98 & 70 & 100 \\
\hline 25 & 66 & 59 & 90 & 61 & 89 \\
\hline 30 & 0 & 9 & 56 & 23 & 78 \\
\hline \multicolumn{6}{|l|}{$\mathrm{pH}$ : growth at } \\
\hline $\mathrm{pH} 5$ & 87 & 32 & 88 & 15 & 0 \\
\hline $\mathrm{pH} 6$ & 97 & 91 & 98 & 77 & 100 \\
\hline $\mathrm{pH} 8$ & 100 & 100 & 100 & 84 & 100 \\
\hline $\mathrm{pH} 9$ & 100 & 91 & 100 & 70 & 89 \\
\hline $\mathrm{pH} 10$ & 100 & 64 & 100 & 23 & 67 \\
\hline \multicolumn{6}{|l|}{ Temperature: growth at } \\
\hline $5^{\circ} \mathrm{C}$ & 94 & 50 & 66 & 0 & 11 \\
\hline $15^{\circ} \mathrm{C}$ & 97 & 63 & 98 & 30 & 11 \\
\hline $40^{\circ} \mathrm{C}$ & 100 & 91 & 100 & 54 & 22 \\
\hline $45^{\circ} \mathrm{C}$ & 94 & 82 & 64 & 23 & 22 \\
\hline Strict aerobes* & 0 & 100 & 100 & 100 & 100 \\
\hline Oxidase* & 100 & 100 & 30 & 100 & 100 \\
\hline \multicolumn{6}{|l|}{ Acid production from: } \\
\hline L-Arabinose* & 100 & 9 & 4 & 0 & 11 \\
\hline D-Cellobiose* & 100 & 9 & 4 & 0 & 0 \\
\hline D-Galactose* & 100 & 5 & 48 & 0 & 0 \\
\hline Glycerol $^{*}$ & 98 & 9 & 6 & 8 & 33 \\
\hline D-Glucose* & 98 & 0 & 64 & 0 & 0 \\
\hline meso-Inositol $^{*}$ & 100 & 0 & 2 & 0 & 33 \\
\hline Lactose* & 94 & 0 & 4 & 8 & 11 \\
\hline Maltose ${ }^{*}$ & 93 & 0 & 2 & 0 & 11 \\
\hline D-Mannitol* & 100 & 0 & 4 & 8 & 0 \\
\hline Rhamnose* & 94 & 0 & 0 & 0 & 22 \\
\hline Sucrose* & 100 & 0 & 6 & 0 & 0 \\
\hline $\mathrm{H}_{2} \mathrm{~S}$ production & 53 & 64 & 46 & 30 & 11 \\
\hline Nitrate reduction to nitrite & 26 & 50 & 76 & 38 & 100 \\
\hline Nitrite reduction to gas & 8 & 25 & 14 & 30 & 89 \\
\hline Phenylalanine deaminase* & 14 & 0 & 82 & 0 & 0 \\
\hline \multicolumn{6}{|l|}{ Degradation of: } \\
\hline Aesculin & 76 & 9 & 20 & 15 & 44 \\
\hline Blood* & 98 & 45 & 6 & 0 & 0 \\
\hline Casein* & 91 & 9 & 2 & 8 & 0 \\
\hline DNA & 96 & 50 & 14 & 0 & 44 \\
\hline Gelatin & 100 & 59 & 10 & 15 & 89 \\
\hline Starch & 11 & 0 & 8 & 0 & 0 \\
\hline Tween 20 & 94 & 86 & 40 & 100 & 89 \\
\hline Tween 80 & 83 & 81 & 8 & 84 & 55 \\
\hline Urea & 14 & 81 & 82 & 84 & 44 \\
\hline
\end{tabular}


Table 1 (continued)

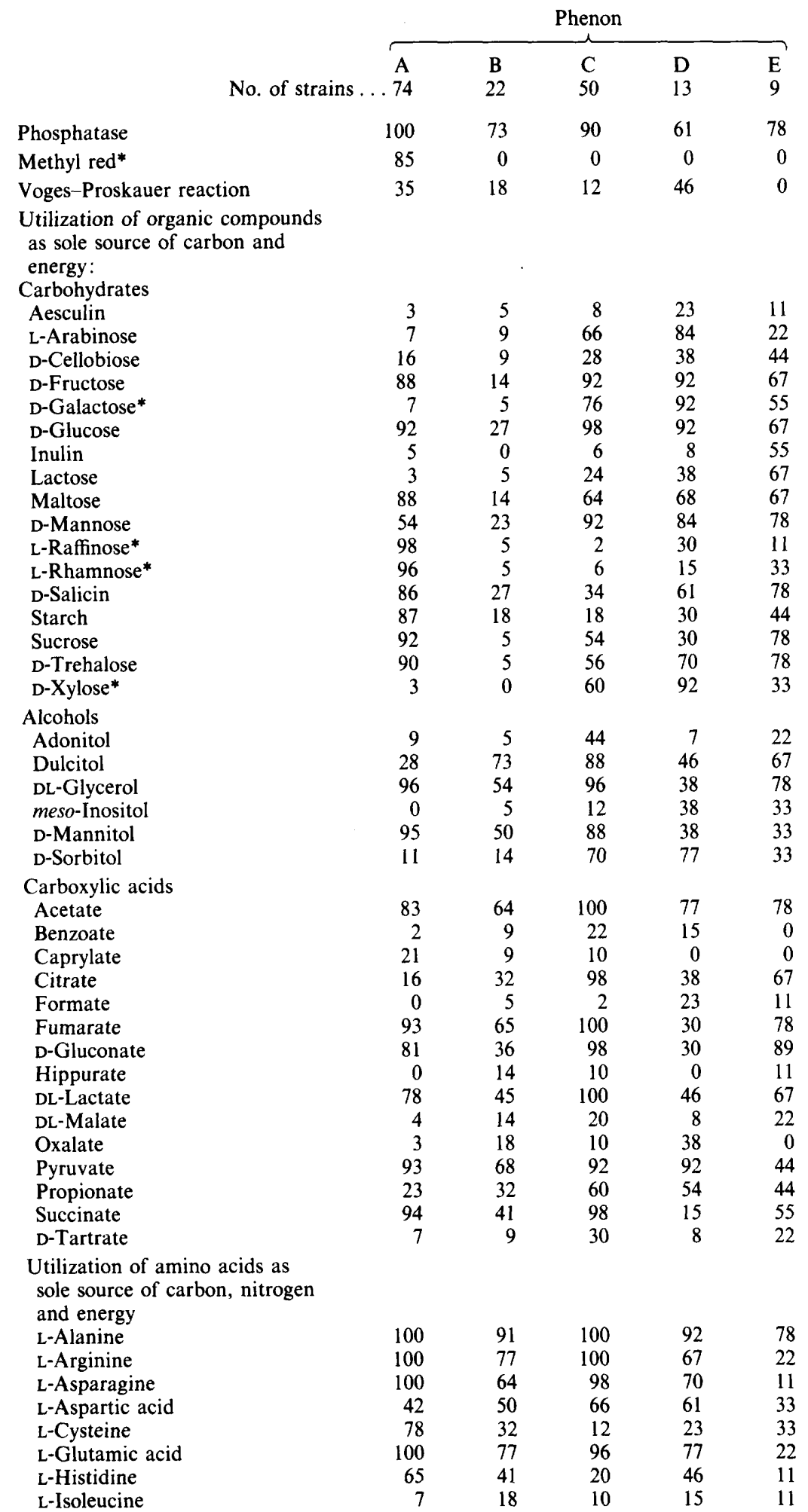


Table 1 (continued)

\begin{tabular}{|c|c|c|c|c|c|}
\hline & \multicolumn{4}{|c|}{ Phenon } \\
\hline & & B & $\mathrm{C}$ & $\mathrm{D}$ & $\mathrm{E}$ \\
\hline & No. of strains . . 74 & 22 & 50 & 13 & 9 \\
\hline L-Leucine & 10 & 23 & 18 & 23 & 0 \\
\hline L-Lysine & 15 & 36 & 34 & 38 & 0 \\
\hline L-Ornithine & 100 & 77 & 94 & 92 & 89 \\
\hline L-Serine & 88 & 68 & 98 & 77 & 44 \\
\hline L-Tryptophan & 0 & 0 & 2 & 8 & 0 \\
\hline L-Valine & 8 & 0 & 4 & 8 & 11 \\
\hline \multicolumn{6}{|l|}{ Susceptibility to: } \\
\hline Ampicillin & 100 & 95 & 98 & 100 & 89 \\
\hline Cephalothin & 73 & 91 & 58 & 92 & 100 \\
\hline Erythromycin & 93 & 95 & 52 & 92 & 55 \\
\hline Penicillin & 73 & 82 & 62 & 92 & 89 \\
\hline Rifampicin & 100 & 100 & 82 & 92 & 100 \\
\hline Streptomycin & 4 & 5 & 0 & 15 & 0 \\
\hline Tetracycline & 4 & 9 & 0 & 15 & 11 \\
\hline
\end{tabular}

carbohydrates was fermentative; nitrate and nitrite were not reduced. They produced DNAase, and were gelatinolytic, caseinolytic and lipolytic. The $\mathrm{G}+\mathrm{C}$ contents of the DNA from strains A-6 and A-3 were 52.1 and $53.6 \mathrm{~mol} \%$, respectively.

Phenon $B$. This group included $22 \mathrm{Gram}$-negative strains which clustered at $70 \% S$. These were slightly curved rods, motile by one or a few polar flagella. They were strict aerobes, catalase and oxidase positive and showed lipolytic activity. The representative strain B-2 had a G $+\mathrm{C}$ content of $48.6 \mathrm{~mol} \%$.

Phenon $C$. This group contained 50 strains related at $72 \% S$. These were motile or non-motile rods and strict aerobes. All of the motile strains were peritrichously flagellate but 27 strains were oxidase negative and this feature differentiated two subgroups. Strain C-48, representative of the first group of non-motile rods, had a $\mathrm{G}+\mathrm{C}$ content of $63.8 \mathrm{~mol} \%$. The two strains selected from the group of motile rods, C-7 (oxidase negative) and C-26 (oxidase positive), had G + C contents of 64.8 and $67.7 \mathrm{~mol} \%$ respectively.

Phenon $D$. This group comprised 13 strains that clustered at $68 \% S$. These were straight rods, motile by a single polar flagellum. They were aerobes, catalase and oxidase positive. Nitrate and nitrite were not reduced and they did not hydrolyse gelatin or starch. The representative strain D-9 had a $\mathrm{G}+\mathrm{C}$ content of $66.8 \mathrm{~mol} \%$.

Phenon E. The nine strains included in this group clustered at $68 \% S$. These were Gramnegative, oxidase-positive, non-motile rods. All were strict aerobes. They reduced nitrate and nitrite. The majority of these strains had proteolytic, lipolytic and phosphatase activities. None of the strains hydrolysed starch. The G + C content for strain F-3 was $63.8 \mathrm{~mol} \%$.

\section{DISCUSSION}

Our purpose was to classify the moderately halophilic micro-organisms isolated from the inland saltern of La Malá, Granada, in order to compare the flora of this athalassohaline environment with thalassohaline environments, including both waters (Ventosa et al., 1982; Rodriguez-Valera et al., 1985; Marquez et al., 1987) and soils (Quesada et al., 1983).

The majority of the strains studied here were facultatively anaerobic, Gram-negative rods (phenon A) (Fig. 1), which most closely resembled organisms of the genus Vibrio (Baumann et al., 1984b). The type strain of $V$. costicola (NCMB 701) grouped close to phenon A at $60 \% S$ (Fig. 1). However, strains of phenon A differed from the description of $V$. costicola (Baumann et al., 


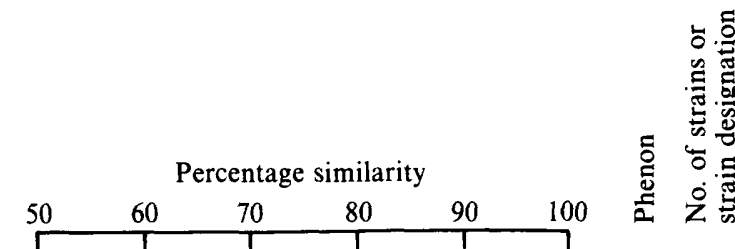

Presumptive identification

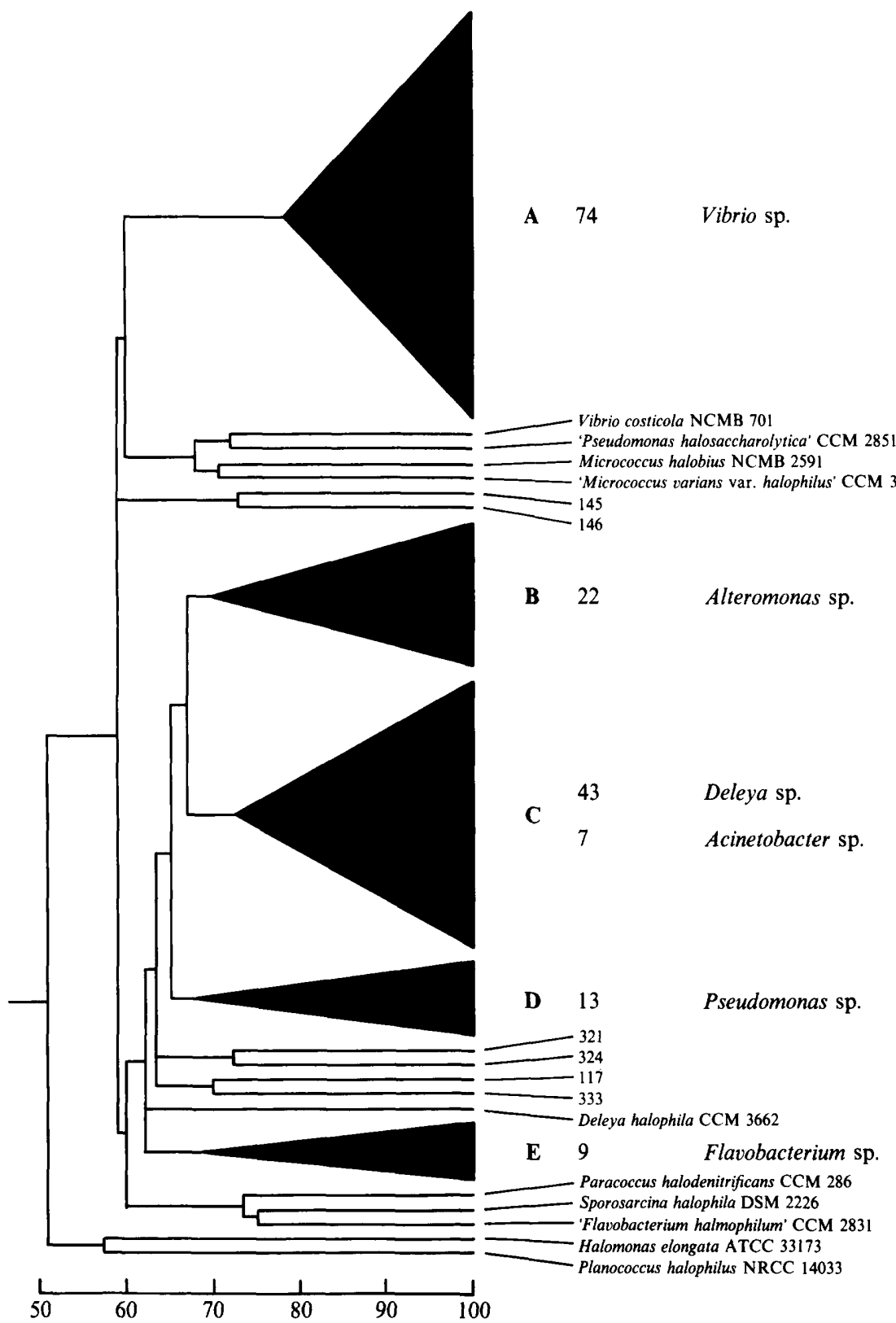

Fig. 1. Simplified dendrogram showing the clustering of strains into five phenons based on the $S_{S M}$ coefficient and UPGMA clustering method for 178 moderately halophilic Gram-negative rods isolated from an inland saltern and 10 reference strains. 
$1984 b$ ) by their ability to produce acids from L-arabinose, D-cellobiose, D-galactose, inositol and lactose. They also hydrolysed casein, were methyl red, DNAase and phosphatase positive, and showed some differences in their response to nutritional tests. Additionally, strains chosen as representatives of phenon $A$ (A-6 and A-3) had $G+C$ contents of 52.1 and $53.6 \mathrm{~mol} \%$, respectively, values which are slightly higher than those accepted for the genus Vibrio (38$51 \mathrm{~mol} \%$ ) and for $V$. costicola (50 mol\%) (Smith, 1938).

Recently, García et al. (1988) proposed an amended description of $V$. costicola on the basis of the examination of 54 moderately halophilic vibrios isolated from several salterns located in different areas in Spain. The strains we have isolated were more similar to the amended description of $V$. costicola, although they differed in that they produced acids from L-arabinose, inositol and D-galactose, and that only $35 \%$ of strains were Voges-Proskauer positive and only $4 \%$ utilized DL-malate and propionate as sole carbon and energy sources.

The Gram-negative, strictly aerobic and motile rods of phenon B most closely resembled organisms in the genus Alteromonas (Baumann et al., 1984a), most of those in phenon C resembled Deleya (Baumann et al., 1983a), and phenon D resembled Pseudomonas (Palleroni, 1984) (Fig. 1). This classification is similar to that reported for other aquatic hypersaline environments (Rodriguez-Valera et al., 1985) in which Gram-negative aerobes constitute the most abundant group ( $50 \%$ of selected strains).

The genus Alteromonas was proposed by Baumann et al. (1972) to accommodate those marine species of Pseudomonas with low G $+\mathrm{C}$ contents (38-50 mol \%). The strains included in phenon B showed the general characteristics of this genus except for the presence of polybetahydroxybutyrate (PHB), growth at $45^{\circ} \mathrm{C}$ and the non-utilization of glucose as sole carbon and energy source by our isolates. Alteromonas communis seems to be the most closely related to our isolates, although it differs by being gelatinase and lipase negative, and in its ability to utilize D-sorbitol and DL-malate as sole carbon and energy source. The primary difference between our isolates and species of the genus Alteromonas is that the former are moderately halophilic microorganisms with higher specific $\mathrm{Na}^{+}$requirements.

The taxonomic assignment of the 13 strains included in phenon $\mathrm{D}$ (Fig. 1) is very problematic. They showed some resemblance to organisms in the genus Pseudomonas (Palleroni, 1984). However, there is only one moderately halophilic species described in this genus, ' $P$. halosaccharolytica' (Hiwatashi et al., 1958), and its type strain (CCM 2851) was not closely associated with this phenon (Fig. 1). However, our isolates seemed to be unrelated to the moderately halophilic and marine species of Pseudomonas so far described, which (except for $P$. nautica) are not lipolytic, do not utilize xylose as sole carbon and energy source and have $\mathrm{G}+\mathrm{C}$ contents lower than the value found for the representative strain of phenon D (55-62 mol \%).

The peritrichously motile rods grouped in phenon $\mathrm{C}$ resembled organisms in the genus Deleya (Baumann et al., 1983a). This includes the species D. cupida, D. pacifica, D. aesta, D. venusta and D. marina, which are marine rod-shaped organisms that are strictly aerobic and without proteolytic, lipolytic or chitinolytic activities. Their $\mathrm{G}+\mathrm{C}$ contents range from 52 to $68 \mathrm{~mol} \%$. Deleya halophila, isolated from hypersaline soils, and the only moderately halophilic species of the genus described to date (Quesada et al., 1984), grouped with phenon C at $64 \% S$.

Among the motile bacteria of phenon $\mathrm{C}$, two groups were distinguished by the oxidase test. Oxidase-negative strains (27) resembled $D$. cupida, from which they differed mainly in that they produced acids from glucose, and in their ability to use different compounds as carbon and energy source. The $\mathrm{G}+\mathrm{C}$ content of strain $\mathrm{C}-7(64.8 \mathrm{~mol} \%)$ was also slightly higher than the range described for this species (60-63 mol\%) (Baumann et al., 1983a). The oxidase-positive strains of this phenon (16) resembled D. pacifica (Baumann et al., 1983a) or D. halophila (Quesada et al., 1984). They differed from the first, however, in that our isolates reduced nitrates and were phenylalanine and phosphatase positive, and when compared with D. halophila they did not produce $\mathrm{H}_{2} \mathrm{~S}$, nor hydrolyse aesculin, casein or DNA. The $\mathrm{G}+\mathrm{C}$ content of a representative of this phenon $(67.7 \mathrm{~mol} \%)$, nevertheless, was very similar to that of $D$. pacifica $(67-68 \mathrm{~mol} \%)$ and D. halophila $(66.7 \mathrm{~mol} \%)$.

The Gram-negative, non-motile, oxidase-negative rods, in phenon C, resembled representatives in the genus Acinetobacter (Juni, 1984). Basic differences between our isolates (seven) and 
A. calcoaceticus were their salt requirements, and their high $\mathrm{G}+\mathrm{C}$ contents compared to the range reported for the genus (38-47 mol\%; Juni, 1984). Recently Quesada et al. (1987) have investigated non-motile moderately halophilic micro-organisms which were selected from various hypersaline habitats. A total of 62 non-motile bacteria was described, 22 of which were oxidase negative and were related to the genus Acinetobacter, from which they differed by nutritional tests and $\mathrm{G}+\mathrm{C}$ contents $(64 \cdot 2-65 \cdot 7 \mathrm{~mol} \%)$; the $\mathrm{G}+\mathrm{C}$ contents were more similar to that of the representative strain studied here $(63.8 \mathrm{~mol} \%)$.

Strains in phenon E (nine strains) (Fig. 1) resembled Flavobacterium oceanosedimentum (Carty \& Litchfield, 1978; Holmes et al., 1984). These strains, together with the seven strains in phenon C that showed similarities with genus Acinetobacter (Juni, 1984), were Gram-negative, nonmotile, aerobic rods. As in other hypersaline environments, this type of micro-organism comprised a low percentage of the moderately halophilic population isolated (10\%) (RodriguezValera et al., 1985; Quesada et al., 1985).

Strains in phenon E also resembled a group of moderately halophilic bacteria we have described recently (Quesada et al., 1987). The only significant difference between the two groups of strains is that the previously reported strains were gelatinase negative (with some exceptions), and some were phenylalanine-deaminase positive.

The genus Flavobacterium (Holmes et al., 1984) includes species with DNA G + C contents of $31-42 \mathrm{~mol} \%$, significantly lower than the value shown by the strain selected to represent phenon E $(63.8 \mathrm{~mol} \%)$. Within the genus Flavobacterium one moderately halophilic species, ' $F$. halmophilum' (Elazari-Volcani, 1940) has been described. This bacterium is now included as species incertae sedis in Bergey's Manual of Systematic Bacteriology (Holmes et al., 1984) as rRNA sequence studies have demonstrated its relation with Alcaligenes aquamarinus (Bauwens $\&$ De Ley, 1981). ' $F$. halmophilum', which grouped with phenon $\mathrm{E}$ at $60 \% \mathrm{~S}$, differed from our isolates in that it had yellow-pigmented colonies, produced acids from several carbohcarbohydrates and did not reduce nitrate to nitrite (Holmes et al., 1984).

\section{REFERENCES}

Baumann, L., Baumann, P., Mandel, M. \& Allen, R. D. (1972). Taxonomy of aerobic marine eubacteria. Journal of Bacteriology 101, 402-429.

BaumanN, L., Bowditch, R. D. \& Baumann, P. (1983a). Description of Deleya gen. nov. created to accommodate the marine species Alcaligenes aestus, $A$. pacificus, $A$. cupidus, $A$. venustus and $P$. marina. International Journal of Systematic Bacteriology 33, 793-802.

Baumann, P., Bowditch, R. D., Baumann, L. \& Baumann, B. (1983b). Taxonomy of marine Pseudomonas species: $P$. stanieri $\mathrm{sp}$. nov.; $P$. perfectomarina sp. nov., nom. rev.; $P$. nautica; and $P$. doudorofii. International Journal of Systematic Bacteriology 33, 857-865.

Baumann, L., Baumann, P., Mandel, M. \& Allen, R. D. (1984a). Genus Alteromonas. In Bergey's Manual of Systematic Bacteriology, vol. 1, pp. 141203. Edited by N. R. Krieg. Baltimore: Williams \& Wilkins

Baumann, P., Furniss, A. L. \& Lee, J. V. (1984b). Genus Vibrio. In Bergey's Manual of Systematic Bacteriology, vol. 1, pp. 518-538. Edited by N. R. Krieg. Baltimore: Williams \& Wilkins.

BAUWENS, M. \& DE LEY, J. (1981). Improvements in the taxonomy of 'Flavobacterium' by DNA-rRNA hybridizations. In The Flavobacterium-Cytophaga Group, pp. 27-31. Edited by H. Reichenbach \& O. B. Weeks. Weinheim: Verlag Chemie.

CARTY, C. F. \& LiTChField, C. D. (1978). Characterization of a new marine sedimentary bacterium as
Flavobacterium oceanosedimentum sp. nov. International Journal of Systematic Bacteriology 28, 561-566. Del Moral, A., Quesada, E. \& Ramos-Cormenzana, A. (1987). Distribution and types of bacteria isolated from an inland saltern. Annales de l'Institut Pasteur/ Microbiologie 131, 59-66.

Elazari-VolCani, B. (1940). Studies on the microflora of the Dead Sea. PhD thesis, Hebrew University, Jerusalem.

Ferragut, C. \& LeClerC, H. (1976). Etude comparative des methodes de determination du Tm de l'ADN bacterien. Annales de Microbiologie 127, 223-235.

Garcia, M. T., Ventosa, A., Ruiz-BerRaQuero, F. \& KocuR, M. (1988). Taxonomic study of Vibrio costicola. International Journal of Systematic Bacteriology (in the Press).

Holmes, B., Owen, R. J. \& McMeexin, T. A. (1984). Genus Flavobacterium. In Bergey's Manual of Systematic Bacteriology, vol. 1, pp. 353-360. Edited by N. R. Krieg. Baltimore: Williams \& Wilkins.

Hiwatashi, T., HaRa, M. \& Yamada, A. (1958). Biological properties of halophilic bacteria no. 101 and no. 203. Journal of the Osaka City Medical Center 7, 550-552.

JACCARD, P. (1908). Nouvelles recherches sur la distribution florale. Bulletin de la société vaudoise des sciences naturelles 44, 223-270.

JunI, E. (1984). Genus Acinetobacter. In Bergey's Manual of Systematic Bacteriology, vol. 1, pp. 141203. Edited by N. R. Krieg. Baltimore: Williams \& Wilkins. 
KUSHNER, D. J. (1978). Life in high salt and solute concentrations: halophilic bacteria. In Microbial Life in Extreme Environments, pp. 317-368. Edited by D. J. Kushner. London: Academic Press.

KUSHNER, D. J. (1985). The Halobacteriaceae. In The Bacteria : a Treatise on Structure and Function, vol. 8, pp. 171-214. Edited by C. R. Woese \& S. R. Wolfe. London: Academic Press.

MARMUR, J. (1961). A procedure for the isolation of deoxyribonucleic acid from microorganisms. Journal of Molecular Biology 3, 208-218.

MARMUR, J. \& DotY, P. (1962). Determination of the base composition of deoxyribonucleic acid from its thermal denaturation temperature. Journal of Molecular Biology 5, 109-118.

Marquez, M. C., Ventosa, A. \& Ruiz-Berraquero, F. (1987). A taxonomic study of heterotrophic halophilic and non-halophilic bacteria from a solar saltern. Journal of General Microbiology 133, 45-56.

MoOre, W. E. C., Cato, E. P. \& Moore, L. V. H. (1985). Index of the bacterial and yeast nomenclatural changes published in the International Journal of Systematic Bacteriology since 1980. Approved Lists of Bacterial Names (1 January 1980 to 1 January 1985). International Journal of Systematic Bacteriology 35, 382-407.

OWEN, R. J. \& HILL, L. R. (1979). The estimation of base compositions, base pairing and genome sizes of bacterial deoxyribonucleic acids. In Identification Methods for Microbiologists, 2nd edn, pp. 227-296. Edited by F. A. Skinner \& D. W. Lovelock. London: Academic Press.

OWen, R. J. \& Pitcher, D. (1985). Current methods for estimating DNA base composition and levels of DNA-DNA hybridization. In Chemical Methods in Bacterial Systematics, pp. 67-93. Edited by M. Goodfellow \& D. E. Minnikin. London: Academic Press.

Palleroni, N. J. (1984). Family Pseudomonadaceae. In Bergey's Manual of Systematic Bacteriology, vol. 1, pp. 141-203. Edited by N. R. Krieg. Baltimore: Williams \& Wilkins.

Quesada, E., Ventosa, A., Rodriguez-Valera, F. \& Ramos-Cormenzana, A. (1982). Types and properties of some bacteria isolated from hypersaline soils. Journal of Applied Bacteriology 53, 155-161.

Quesada, E., Ventosa, A., Rodriguez-Valera, F., Mejias, L. \& Ramos-CoRmenzana, A. (1983). Numerical taxonomy of moderately halophilic Gram-negative bacteria from hypersaline soils. Journal of General Microbiology 129, 2649-2657.
Quesada, E., Ventosa, A., Ruiz-Berraquero, F. \& Ramos-Cormenzana, A. (1984). Deleya halophila, a new species of moderately halophilic bacteria. International Journal of Systematic Bacteriology 34, 287-292.

Quesada, E., Bejar, V., Valderrama, M. J., VenTOSA, A. \& RAMOS-CORMENZANA, A. (1985). Isolation and characterization of moderately halophilic nonmotile rods from different saline habitats. Microbiologia 1, 89-96.

Quesada, E., Valderrama, M. J., Bejar, V., VenTOSA, A., RUIZ-BERRAQUERO, F. \& RAMOS-CORMENZANA, A. (1987). Numerical taxonomy of moderately halophilic Gram-negative nonmotile eubacteria. Systematic and Applied Microbiology 9, 132-137.

Rodriguez-Valera, F., Ventosa, A., Juez, G. \& IMHOFF, J. F. (1985). Variation of environmental features and microbial populations with the salt concentrations in a multi-pond saltern. Microbial Ecology 11, 107-115.

Skerman, V. B. D., McGowan, V. \& SNEaTh, P. H. A. (1980). Approved lists of bacterial names. International Journal of Systematic Bacteriology 30, 225-420.

SMITH, F. B. (1938). An investigation of a taint in rib bones of bacon. The determination of halophilic vibrios (n.spp.). Proceedings of the Royal Society of Queensland 49, 29-52.

SNEATH, P. H. A. \& Johnson, R. (1972). The influence on numerical taxonomic similarities of errors in microbiological tests. Journal of General Microbiology 72, 377-392.

SNEATH, P. H. A. \& SoKal, R. R. (1973). Numerical Taxonomy. The Principles and Practice of Numerical Classification. San Francisco: Freeman.

SOKAL, R. R. \& MicheneR, C. D. (1958). A statistical method for evaluating systematic relationships. University of Kansas Science Bulletin 38, 1409-1438.

Subov, N. N. (1931). Oceanographical tables. Commissariat of Agriculture of USSR Hydro-Meterological Committee of USSR. Moscow: Oceanographical Institute of USSR.

Ventosa, A., Quesada, E., Rodriguez-Valera, F., Ruiz-BERraQuero, F. \& Ramos-Cormenzana, A. (1982). Numerical taxonomy of moderately halophilic Gram-negative rods. Journal of General Microbiology 128, 1959-1968.

Ventosa, A., Ramos-Cormenzana, A. \& Kocur, M. (1983). Moderately halophilic Gram-positive cocci from hypersaline environments. Systematic and Applied Microbiology 4, 564-570. 